\title{
A Virus Serologically Related to Tomato ringspot virus in Blackberries in Rio Grande do Sul, Brazil
}

\author{
Osmar Nickel ${ }^{1}$, Thor V. M. Fajardo ${ }^{1}$, Marcos F. Vanni ${ }^{1}$ \& Eduardo Pagot ${ }^{2}$ \\ ${ }^{1}$ Embrapa Uva e Vinho, Cx. Postal 130, CEP 95700-000, Bento Gonçalves, RS; ${ }^{2}$ Emater, R. Dr. Flores, 240, cj. B, \\ CEP 95200-000, Vacaria, RS, e-mail: nickel@ cnpuv.embrapa.br
}

(Aceito para publicação em 31/08/2004)

Author for correspondence: Osmar Nickel

\begin{abstract}
RESUMO
Vírus sorologicamente relacionado com o Tomato ringspot virus encontrado em amoreiras-pretas no Rio Grande do Sul Vírus relacionado sorologicamente ao Tomato ringspot virus (ToRSV) foi detectado em plantas de juá (Solanum viarum) procedente de Vacaria (Campos de Cima da Serra), RS, mostrando forte mosaico e presentes nas entrelinhas de amoreiras-pretas. Foi transmitido mecanicamente desta invasora e de amoreiras-pretas (Rubus sp.) para Chenopodium quinoa, na qual induziu distorções foliares e distorção apical do caule, enfezamento geral, manchas diminutas cloróticas e necróticas nas folhas. O vírus em extratos foliares reagiu positivamente em DAS-ELISA com um anti-soro comercial contra o isolado Peach yellow bud mosaic (PYBM) de ToRSV mas não com um anti-soro do isolado Chickadee $(\mathrm{CH})$ do mesmo vírus. As amoreiras-pretas infetadas não mostravam sintomas perceptíveis.
\end{abstract}

Blackberries (Rubus sp.) are becoming an economically and socially important crop in regions of Southern Brazilian with subtropical climates. Their production bears great potential for integrating small farmers into cash crop markets. Tomato ringspot virus (ToRSV) (Comoviridae; Nepovirus), one of the most widespread and economically important viruses causing diseases in Rubus spp. (ringspots, delayed foliation, reduced drupelet set and fruit size in some varieties) is also associated with diseases of fruit crops, including peach [Prunus persicae (L.) Batscgh], grape (Vitis spp.), sweet cherry (Prunus serotina Ehrh.), prune (Prunus domestica L.), blueberry (Vaccinium corymbosum L.), apple (Malus domestica Borkh) and strawberry (Fragaria x ananassa Duchesne), (Stace-Smith, R., C.M.I. Descriptions of Plant Viruses no. 290, Commonwealth Mycological Institute, England. 1970). Virus inocula prepared from infected Solanum viarum Dun. "juá" plants growing between rows of blackberries induced in quinoa (Chenopodium quinoa Willd.) test plants general stunting, stem apex and varied leaf distortions, and foliar chlorotic pinpoint spotting that turned into necrotic lesions. Extracts of infected quinoa reacted positively to ToRSV antiserum in DAS-ELISA. Blackberry germplasm from the
U.S.A. is the source of planting materials used in Brazil. It is therefore of interest to investigate the occurrence of this virus and how it could spread into blackberry propagative material. As a first approach to evaluating the incidence of this mechanically-transmissible virus in blackberries, at least six plant samples were collected in each of four locations in Vacaria, RS. Buffered plant sap of leaves, flowers and fruits of the widely planted cvs. Tupy and Guarany was used to mechanically inoculate quinoa plants. Twelve days later leaf samples from the inoculated plants, showing the symptoms previously described, were analysed by DAS-ELISA with antisera to the Chickadee $(\mathrm{CH})$ and Peach yellow bud mosaic (PYBM) isolates of ToRSV. Most Tupy and a few Guarany samples reacted positively to ToRSV-PYBM-isolate antiserum and none to the ToRSV-CH antiserum. The biological spectrum of PYBM-antisera, is very wide; they react with ToRSV isolates from Canada, USA and Europe (Bitterlin \& Gonsalves, Phytopathology 78: 278. 1988). ToRSV is graft-transmissible, hosted by several weeds (e.g. Taraxacum officinale Web.) and spread by nematodes. Therefore this finding is relevant for adoption of additional control practices and for consideration in plant transport, exchange and trade. 